\title{
Community Genetics
}

No. 1

1 Editorial

Review

2 The Integration of Genomics into Public Health Research, Policy and Practice in the United States

Beskow, L.M. (Atlanta, Ga./Chapel Hill, N.C.); Khoury, M.J.; Baker, T.G. (Atlanta, Ga.); Thrasher, J.F. (Atlanta, Ga./Chapel Hill, N.C.)

\section{Commentary}

12 Current Challenges to Appropriate Clinical Use of New Genetic Knowledge in Different Countries

Baird, P.A. (Vancouver)

Original Papers

18 Public Attitudes regarding the Donation and Storage of Blood Specimens for Genetic Research

Wang, S.S.; Fridinger, F.; Sheedy, K.M.; Khoury, M.J. (Atlanta, Ga.)

27 Finnish Physicians' Interest in Genetic Screening

Toiviainen, H.; Hemminki, E. (Helsinki)

36 Disease Knowledge and Attitudes toward Predictive Testing and Prenatal Diagnosis in Families with Machado-Joseph Disease from the Azores Islands (Portugal)

Lima, M.; Kay, T.; Vasconcelos, J.; Mota-Vieira, L.; Gonzalez, C.; Peixoto, A. (St. Miguel); Abade, A. (Coimbra); MacLeod, P. (Victoria); Graça, R. (Terceira); Santos, J. (St. Miguel)

43 Triple Test Screening for Down Syndrome: Looking Back on a False-Positive Result and Having or Not Having a Triple Test in Subsequent Pregnancies

Evers-Kiebooms, G.; Nys, K.; Decruyenaere, M.; Witters, I.; Fryns, J.-P. (Leuven)

50 The Tyr978X BRCA1 Mutation in Non-Ashkenazi Jews: Occurrence in High-Risk Families, General Population and Unselected Ovarian Cancer Patients

Shiri-Sverdlov, R. (Tel-Hashomer); Gershoni-Baruch, R. (Haifa);

Ichezkel-Hirsch, G.; Gotlieb, W.H.; Bruchim Bar-Sade, R.; Chetrit, A.;

Rizel, S.; Modan, B.; Friedman, E. (Tel-Hashomer)

Conference Report

56 Community Genetics and Its Evaluation: A European Science Foundation Workshop

Henneman, L.; Langendam, M.W.; ten Kate, L.P. (Amsterdam)

60 Book Review
No. 2

Reviews

61 Global Perspectives of Familial Hypercholesterolemia Fouchier, S.W.; Defesche, J.C.; Kastelein, J.J.P. (Amsterdam)

68 Creating Needs? A Review of Survey Data and Concerns Relevant to the Commercialization of Genetic Testing Caulfield, T. (Edmonton); Wertz, D. (Waltham, Mass.)

Commentaries

77 The Human Genome Project, Genetics and Health Baird, P. (Vancouver)

81 On the Role of Clinical Genetics in 2010

Schmidtke, J. (Hannover)

Opinions

84 Extending Antenatal Screening in the UK to Include Common Monogenic Disorders

Cuckle, H. (Leeds)

87 Bottom Line Genetics. Commentary to Cuckle Lippman, A. (Montreal)

Original Papers

90 Development, Implementation and Evaluation of Protocols for the Management of Women and Children in South Texas Who Are at Risk for Genetic and Other Birth Disorders Kolb, S.E.; Aguilar, M.C.; Dineneberg, M.W.; Kaye, C.I. (San Antonio, Tex.)

97 A Population-Based Estimate of the Prevalence of Consanguineous Marriage in Western Australia Port, K.; Bittles, A.H. (Perth)

102 The Role of Family History in Personal Prevention Practices among US Women Physicians

Saraiya, M.; Coughlin, S.S. (Atlanta, Ga.); Burke, W. (Seattle, Wash.); Elon, L.K.; Frank, E. (Atlanta, Ga.)

109 Clinical Etiological Survey of a Population of 471 Mentally Retarded Patients Living in an Institution in the Southern Part of the Netherlands

Van Buggenhout, G.J.C.M. (Leuven/Nijmegen); Trommelen, J.C.M (Udenhout); Brunner, H.G.; Hamel, B.C.J. (Nijmegen); Fryns, J.-P. (Leuven)

Short Communications

123 Familial Hypercholesterolaemia: Taking Advantage of a Founder Effect for Early Diagnosis and Treatment Miltiadous, G. (Ioannina); Cariolou, M.A. (Nicosia); Elisaf, M. (Ioannina)

125 Distribution of Two X-Linked Trinucleotide Polymorphisms in Greece

Syrrou, M. (Ioannina); Yapijakis, C. (Athens); Bouba, I.; Adamidis, K. (Ioannina); Vassilipoulos, D. (Athens); Georgiou, I. (Ioannina)

128 Announcement

\section{KARGER}

Fax +41613061234 E-Mail karger@karger.ch www.karger.com
(C) 2002 S. Karger AG, Basel

Access to full text and tables of contents, including tentative ones for forthcoming issues: www.karger.com/journals/cmg/cmg_bk.htm 
No. 3

Original Papers

129 Psychological Impact of Preconception Counseling: Assessment of Anxiety before and during Pregnancy De Weerd, S.; Van der Bij, A.K.; Braspenning, J.C.C.; Cikot, R.J.L.M.; Braat, D.D.M. (Nijmegen); Steegers, E.A.P. (Rotterdam)

134 Population-Based Estimates of the Prevalence of Family History of Cancer among Women

Hall, I.J. (Atlanta, Ga.); Burke, W. (Seattle, Wash.); Coughlin, S.; Lee, N.C. (Atlanta, Ga.)

143 Opportunities for Public Health Genetics Trainees: Results of an Employer/Workplace Survey

Austin, M.A. (Seattle, Wash.); Arnett, D. (Minneapolis, Minn.); Beaty, T. (Baltimore, Md.); Durfy, S. (Seattle, Wash.); Fineman, R. (Olympia, Wash.); Gettig, E. (Pittsburgh, Pa.); Lochner Doyle, D. (Kent, Wash.); Peyser, P. (Ann Arbor, Mich.); Sorenson, J. (Chapel Hill, N.C.); Thompson, J.D.; Watts, C. (Seattle, Wash.)

148 The Frequency of Inherited Disorders Database: Prevalence of Huntington Disease

Al-Jader, L.N.; Harper, P.S.; Krawczak, M.; Palmer, S.R. (Cardiff)

158 Participation in Maternal Marker Screening for Down Syndrome: Contribution of the Information Delivered to the Decision-Making Process

Seror, V.; Costet, N. (Le Kremlin-Bicêtre); Aymé, S. (Paris)

Letters to the Editor

173 Reply to Prof. A. Lippman's Commentary in the Previous Issue Cuckle, H. (Leeds)

174 Reply to Prof. H. Cuckle Lippman, A. (Montreal)

Report

175 Integrating Genetic Services into Public Health - Guidance for State and Territorial Programs from the National Newborn Screening and Genetics Resource Center (NNSGRC)

Edited by: Kaye, C.I. (San Antonio, Tex.); Laxova, R. (Madison, Wisc.); Livingston, J.E. (San Antonio, Tex./Austin, Tex.); Lloyd-Puryear, M.A.; Mann, M. (Rockville, Md.); McCabe, E.R.B. (Los Angeles, Calif.); Therrell, B.L. (San Antonio, Tex./Austin, Tex.)

Book Review
No. 4

Reviews

197 Alzheimer's Disease: Genes, Pathogenesis and Risk Prediction Sleegers, K.; van Duijn, C.M. (Rotterdam)

204 Ethical, Social and Legal Implications of Pharmacogenomics: A Critical Review

Møldrup, C. (Copenhagen)

Opinion

215 Genetics, Primary Care and Families. What Do Families Need? Kent, A. (London)

Original Papers

219 Life and Health Insurance Behaviour of Individuals Having Undergone a Predictive Genetic Testing Programme for Hereditary Non-Polyposis Colorectal Cancer Aktan-Collan, K. (Helsinki); Haukkala, A. (Helsinki/Boston, Mass.); Kääriäinen, H. (Helsinki)

225 Detection of Congenital Anomalies by Fetal Ultrasonographic Examination across Europe

Stoll, C (Strasbourg); Tenconi, R.; Clementi, M. (Padova); and the Euroscan Study Group

233 Counselling following the Prenatal Diagnosis of Klinefelter Syndrome: Comparisons between Geneticists and Obstetricians in Five European Countries

Hall, S.; Marteau, T.M.; Limbert, C. (London); Reid, M. (Glasgow); Feijóo, M.; Soares, M. (Lisbon); Nippert, I. (Münster); Bobrow, M. (Cambridge); Cameron, A. (Glasgow); van Diem, M.; VerschuurenBemelmans, C. (Groningen); Eiben, B. (Oberhausen); García-Miñaur, S. (Barakaldo); Walkinshaw, S. (Liverpool); Soothill, P. (Bristol); de Vigan, C. (Paris); McIntosh, K. (Glasgow); Kirwan, D. (Liverpool)

239 The Opinions, Expectations and Experiences of Women with a Family History of Breast Cancer Who Consult Their GP and Are Referred to Secondary Care

Andermann, A.A.J.; Watson, E.K.; Lucassen, A.M.; Austoker, J. (Oxford)

244 How Disturbing Is It to Be Approached for a Genetic Cascade Screening Programme for Familial Hypercholesterolaemia? Psychological Impact and Screenees' Views

van Maarle, M.C.; Stouthard, M.E.A.; Marang-v.d. Mheen, P.J.; Klazinga, N.S.; Bonsel, G.J. (Amsterdam)

253 Acknowledgement to Reviewers

254 Author Index Vol. 4, 2001

255 Subject Index Vol. 4, 2001 